\title{
Multiple early Eocene carbon isotope excursions associated with environmental changes in the Dieppe-Hampshire Basin (NW Europe)
}

\author{
Sylvain Garel ${ }^{1,2,3, *}$, Christian Dupuis ${ }^{4}$, Florence Quesnel ${ }^{2,3}$, Jérémy Jacob ${ }^{2,5}$, Johan Yans ${ }^{6}$, \\ Roberto Magioncalda ${ }^{7}$, Christine Fléhoc ${ }^{8}$ and Johann Schnyder ${ }^{1}$ \\ 1 Sorbonne Université, CNRS-INSU, ISTeP UMR 7193, 4, Place Jussieu, 75005 Paris, France \\ ${ }^{2}$ Université d'Orléans, CNRS, BRGM, Institut des Sciences de la Terre d'Orléans (ISTO), UMR 7327, 45071 Orléans, France \\ ${ }^{3}$ BRGM GéoRessources/GAT, 45060 Orléans Cedex 2, France \\ ${ }^{4}$ Laboratoire de Géologie Fondamentale et Appliquée, Faculté Polytechnique de Mons, Université de Mons, rue de Houdain 9, 7000 \\ Mons, Belgium \\ ${ }^{5}$ Laboratoire des Sciences du Climat et de l'Environnement, CEA-CNRS-UVSQ, Université Paris-Saclay, 91198 Gif-sur-Yvette, France \\ ${ }^{6}$ University of Namur, Department of Geology, Institute of Life, Earth and Environment, ILEE, 61, rue de Bruxelles, 5000 Namur, \\ Belgium \\ ${ }^{7}$ FRAMATOME, HPC Project, 1, Place Jean Miller, 92400 Courbevoie, France \\ 8 BRGM Direction des Laboratoires/ISO, 45060 Orléans Cedex 2, France
}

Received: 14 November 2019 / Accepted: 26 June 2020

\begin{abstract}
The early Eocene experienced a series of short-lived global warming events, known as hyperthermals, associated with negative carbon isotope excursions (CIE). The Paleocene-Eocene Thermal Maximum (PETM or ETM-1) and Eocene Thermal Maximum 2 (ETM-2) are the two main events of this Epoch, both marked by massive sea-floor carbonate dissolution. Their timing, amplitude and impacts are rather well documented, but CIEs with lower amplitudes also associated with carbonate dissolution are still poorly studied (e.g. events E1 to $\mathrm{H} 1$ ), especially in the terrestrial realm where hiatus/disconformities and various sedimentary rates in a single succession may complicate the assignation to global isotopic events. Here we present a new high-resolution multi-proxy study on the terrestrial, lagoonal and shallow marine late Paleocene-early Eocene succession from two sites of the Cap d'Ailly area in the Dieppe-Hampshire Basin (Normandy, France). Carbon isotope data $\left(\delta^{13} \mathrm{C}\right)$ on bulk organic matter and higher-plant derived $n$-alkanes, and $\mathrm{K}-\mathrm{Ar}$ ages on authigenic glauconite were determined to provide a stratigraphic framework. Palynofacies, distribution and hydrogen isotope values $\left(\delta^{2} \mathrm{H}\right)$ of higher-plant derived $n$-alkanes allowed us to unravel paleoenvironmental and paleoclimatic changes. In coastal sediments of the Cap d'Ailly area, $\delta^{13} \mathrm{C}$ values revealed two main negative CIEs, from base to top CIE1 and CIE2, and 3 less pronounced negative excursions older than the NP11 nannofossil biozone. While the CIE1 is clearly linked with the PETM initiation, the CIE2 could either correspond to 1) a second excursion within the PETM interval caused by strong local environmental changes or 2) a global carbon isotopic event that occurred between the PETM and ETM-2. Paleoenvironmental data indicated that both main CIEs were associated with dramatic changes such as eutrophication, algal and/or dinoflagellate blooms along with paleohydrological variations and an increase in seasonality. They revealed that the intervals immediately below these CIEs are also marked by environmental and climatic changes. Thus, this study shows either 1) a PETM marked by at least two distinct intervals of strong environmental and climatic changes or 2) at least one "minor" CIE: E1, E2, F or G, was associated with strong environmental and climatic changes similar to those that occurred during the PETM.
\end{abstract}

Keywords: early Eocene / carbon isotope excursions / PETM / paleohydrology / palynofacies / Dieppe-Hampshire Basin

*Corresponding author: sylvain.garel.laurin@gmail.com 
Résumé - Multiples excursions isotopiques du carbone de l'Eocène inférieur associées à des changements environnementaux dans le Bassin de Dieppe-Hampshire (Europe du NO). L'Eocène inférieur fût le théâtre d'une série de réchauffements climatiques rapides et globaux nommés hyperthermaux qui sont associés à des excursions isotopiques négatives du carbone $(\mathrm{CIE}=$ Carbon Isotope Excursion $)$. Le maximum thermique du Paléocène-Eocène (PETM=Paleocene-Eocene Thermal Maximum ou ETM$1=$ Eocene Thermal Maximum-1) et le Maximum Thermique de 1'Eocène-2 (ETM-2) sont les deux évènements principaux de cette Epoque et sont tous les deux marqués par la dissolution massive de carbonates des fonds marins. Leurs timings, amplitudes et impacts sont plutôt bien documentés, mais des CIEs de plus faible amplitude, également associées à des dissolutions de carbonates, sont encore peu étudiées (p. ex. évènements E1 à H1), notamment dans le domaine continental où les hiatus/inconformités ainsi que les taux de sédimentation variables dans une même succession compliquent l'identification des évènements isotopiques globaux. Ici, nous présentons une nouvelle étude "multi-proxy » à haute résolution sur la succession continentale, lagunaire et marine peu profonde de deux sites du secteur du Cap d'Ailly dans le Bassin de Dieppe-Hampshire (Normandie). Les données isotopiques du carbone $\left(\delta^{13} \mathrm{C}\right)$ de la matière organique totale et des $n$-alcanes de végétaux supérieurs ainsi que les âges $\mathrm{K}-\mathrm{Ar}$ de glauconies authigènes ont été déterminés pour obtenir un cadre stratigraphique robuste. Les palynofaciès ainsi que la distribution et les données isotopiques de l'hydrogène $\left(\delta^{2} \mathrm{H}\right)$ de $n$-alcanes de végétaux supérieurs nous ont permis de reconstituer les changements paléoenvironnementaux et paléoclimatiques survenus durant l'intervalle étudié. Dans les sédiments côtiers du secteur du Cap d'Ailly, les courbes de $\delta^{13} \mathrm{C}$ montrent 2 principales CIEs négatives, de la base au sommet: CIE1 et CIE2, et 3 excursions négatives moins prononcées, toutes plus anciennes que la biozone à nannofossiles NP11. Alors que la CIE1 est clairement liée à l'initiation du PETM, la CIE2 pourrait correspondre, soit 1) à une seconde excursion au sein du PETM causée par un important changement environnemental local, soit 2) à un évènement isotopique du carbone global qui ce serait produit entre le PETM et l'ETM-2. Les données paléoenvironnementales indiquent que les deux principales CIEs sont associées à des changements importants comme l'eutrophisation, des proliférations d'algues et/ou de dinoflagellés associés à des variations paléohydrologiques et à une augmentation de la saisonnalité. Elles révèlent que les intervalles immédiatement sous les CIEs sont aussi marqués par des changements environnementaux et climatiques. Ainsi, cette étude montre que : soit 1) le PETM fut marqué par au moins deux intervalles distincts de forts changements environnementaux et climatiques, ou 2) qu'au moins une CIE mineure : E1, E2, F ou G fut associée à des changements environnementaux et climatiques similaires à ceux qui se sont produits pendant le PETM.

Mots clés : Eocène inférieur / excursions isotopiques du carbone / PETM / paléohydrologie / palynofaciès / Bassin de Dieppe-Hampshire

\section{Introduction}

The late Paleocene and early Eocene were marked by a series of extreme and fast transient global hyperthermal events (Cramer et al., 2003; Lourens et al., 2005; Coccioni et al., 2012; Westerhold et al., 2018). During these events, global average temperatures eventually rose by as much as $7^{\circ} \mathrm{C}$ above pre-hyperthermal ones (McInerney and Wing, 2011; Krishnan et al., 2014). The hyperthermals are all characterized by carbonate dissolution horizons in marine successions and negative carbon isotope excursions (CIE) linked to the release of a large amount of isotopically depleted carbon in the oceanatmosphere system (Lourens et al., 2005; Zachos et al., 2005; Littler et al., 2014). The largest hyperthermal, the PaleoceneEocene Thermal Maximum (PETM or ETM-1), occurred around $56 \mathrm{Ma}$ (Westerhold et al., 2017) and was associated with benthic foraminifera extinction in oceans (Kennett and Stott, 1991) and the appearance and rapid dispersal of modern mammalian orders on land (Smith et al., 2006). Other wellknown warming events such as ETM-2 (or ELMO; 54 Ma) and ETM-3 (or "X" event; $52.8 \mathrm{Ma}$ ) occurred during the early Eocene (Lauretano et al., 2015; Westerhold et al., 2017). They had a smaller impact on climate and on the terrestrial fauna (Abels et al., 2016; Noiret et al., 2016).
Cramer et al. (2003) showed that four events, "E1", "E2", "F" and "G", still poorly studied, occurred between PETM and ETM-2, respectively 250, 350, 750 and $940 \mathrm{ka}$ after the PETM (Westerhold et al., 2017). Their CIE magnitudes are much smaller than that of the PETM, even though the "E1" CIE magnitude can reach half of that of the PETM in Italy (Coccioni et al., 2012). These events are associated to a decrease in $\delta^{18} \mathrm{O}$ values and in carbonate content (Coccioni et al., 2012), but their climatic and environmental impacts have never been discussed in detail, especially on land.

In France, Upper Paleocene and Lower Eocene terrestrial and lagoonal sediments corresponding to the regional "Sparnacian" stage are known to record the PETM and are found in the Corbieres (South of France, Yans et al., 2014), Paris and Dieppe-Hampshire basins among others (Aubry et al., 2005). In the Dieppe-Hampshire Basin, these Sparnacian facies are well exposed to the west of Dieppe (Normandy; Fig. 1) with a maximum thickness of $15 \mathrm{~m}$ in the Cap d'Ailly area. The coastal swamp sediments of this area record the PETM and dramatic environmental changes in the lower lignite complex (L1) of the Mortemer Formation representing only a fraction of the Sparnacian succession (Magioncalda et al., 2001; Storme et al., 2012; Garel et al., 2013). 


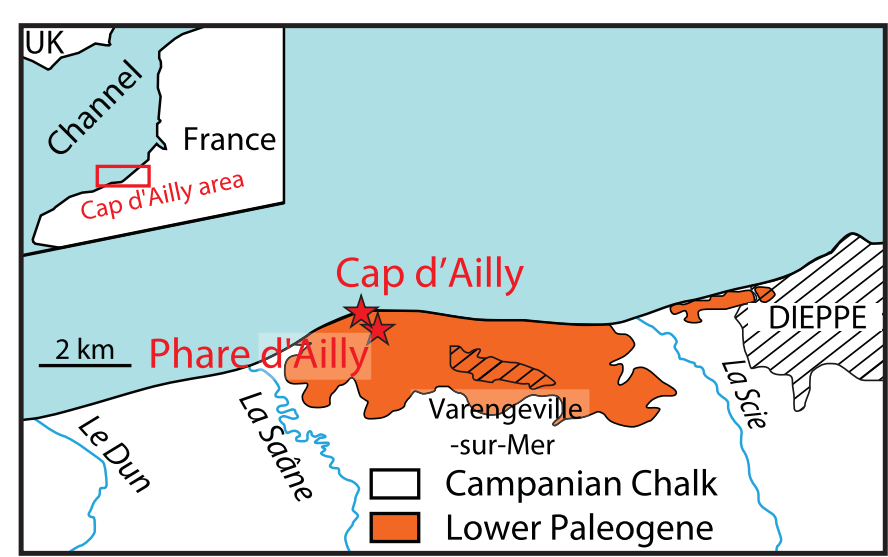

Fig. 1. location of the Cap d'Ailly composite section and the Phare d'Ailly borehole within the Cap d'Ailly area.

Here we present a multi-proxy study of the Phare d'Ailly core that displays almost the whole local Sparnacian sedimentary succession. Compound-specific $\delta^{13} \mathrm{C}$ values and $\mathrm{K}-\mathrm{Ar}$ ages on authigenic glauconite were determined and compared to micropaleontology and palynology records to build a stratigraphic framework and unravel CIEs. Palynofacies and relative abundances and distributions of $n$-alkanes provided clues about vegetation succession and other environmental changes. Paleohydrological changes were constrained by $\delta^{2} \mathrm{H}$ values of $n$-alkanes. Our integrated data unravel climatic and environmental changes at other time intervals than the one occurring at the Paleocene-Eocene boundary and their possible link with carbon isotopic events in this mid-latitude coastal environment.

\section{Sample locations and methodology}

\subsection{Geological setting}

The Cap d'Ailly area in northern France (Fig. 1) displays a series of expanded late Paleocene-early Eocene sedimentary sections corresponding to terrestrial and lagoonal environments that outcrop on top of the Cap d'Ailly cliffs (Dupuis et al., 1998; Magioncalda et al., 2001). These Paleogene sediments are divided into three Formations (Fig. 2; Dupuis et al., 1998): (i) the Mortemer Fm is best known for its uppermost lacustrine-palustrine Member, the "Calcaire du Cap d'Ailly" (CCA) Mb; (ii) the Soissonnais Fm begins with the lagoonal "Sables et Argiles à Ostracodes et Mollusques" (SAOM) $\mathrm{Mb}$ that is overlain by the marine clay of the Craquelins Mb (Fig. 2); (iii) the transgressive Varengeville Fm first displays three glauconitic clayey sand units (FV1 to FV3) that are overlain by two clay units (FV4 and FV5) separated from each other by a glauconitic and bioclastic sand bed. In this area, previous studies have established the Paleocene-Eocene boundary $(\mathrm{P}-\mathrm{Eb})$ and the PETM within the CCA Mb, in the L1 lignite complex (Magioncalda et al., 2001). They also revealed the presence of four less pronounced negative carbon isotope peaks and excursions: $\mathrm{P}_{1}, \mathrm{P}_{2}, \mathrm{CIE} 2$ and CIE3 (Fig. 2; Magioncalda, 2004). Finally, nannofossils of the NP11 biozone were found across the junction of units FV4 and FV5 (Aubry, 1983 ) indicating that their age is younger than the PETM by at least 1.6 Ma (Vandenberghe et al., 2012).
The Phare d'Ailly borehole, drilled by the BRGM near the Cap d'Ailly section, displays $9 \mathrm{~m}$ of Sparnacian sediments, including $1.8 \mathrm{~m}$ of the CCA Mb, $6.1 \mathrm{~m}$ of the SAOM Mb and $95 \mathrm{~cm}$ of the Craquelins Mb (Fig. 3). The CCA Mb is mainly characterized by $1 \mathrm{~m}$ of lignite and alternations of organic-rich marl, silt and clay beds that overlay fluvial sands and a lacustrine limestone. The SAOM Mb, split in two units by a lignite complex L2 and its subjacent paleosol, displays an alternation of sand, silt, clay and coquina beds. The uppermost SAOM is also characterized by the presence of oyster shells and of a siderite nodules bed that marks the base of a decalcification interval at its top. Finally, the Craquelins Clay $\mathrm{Mb}$ consists of dark green glauconitic clay and silts.

\subsection{Bulk organic matter $\delta^{13} \mathrm{C}$}

Sixty-six samples from the Phare d'Ailly core were prepared according to the method described by Magioncalda et al. (2004) and modified by Yans et al. (2010). After decarbonation, organic matter $(\mathrm{OM})$ enriched residues were analyzed with a ThermoFinnigan Flash EA 1112 coupled with a ThermoFinnigan Delta Vplus mass spectrometer (MS). $\delta^{13} \mathrm{C}$ values based on duplicate analyses were calculated against a calibrated $\mathrm{CO}_{2}$ gas and normalized to the VPDB scale.

\subsection{Lipid extraction, separation and analysis}

Thirty dried and powdered samples were extracted with an Accelerated Solvent Extractor (ASE 200, Dionex(C) using a solvent mixture of dichloromethane (DCM):methanol 9:1 $(v / v)$. Extracted lipids were first separated by solid phase extraction into neutrals and acidic compounds and then into aliphatic hydrocarbons and polar compounds with Kieselgel-type-silica columns, according to the protocol described in Garel et al. (2013). The aliphatic hydrocarbons were dissolved in toluene and $5 \alpha$-Cholestane was added as internal standard.

GC-MS analyses were performed on a Trace GC Ultra interfaced with a TSQ Quantum XLS MS. The GC was fitted with a Trace Gold TG-5 MS capillary column $(60 \mathrm{~m} \times 0.25$ $\mathrm{mm}$ i.d., $0.25 \mu \mathrm{m}$ film thickness). GC operating conditions were as follows: temperature hold at $40^{\circ} \mathrm{C}$ for $1 \mathrm{~min}$, then an increase from 40 to $120^{\circ} \mathrm{C}$ at $30^{\circ} \mathrm{C} / \mathrm{min}, 120$ to $300^{\circ} \mathrm{C}$ at $3{ }^{\circ} \mathrm{C} /$ min with a final isothermal hold at $300^{\circ} \mathrm{C}$ for $70 \mathrm{~min}$. Samples were injected in splitless mode in a $2 \mu \mathrm{l}$ volume with the injector temperature at $280^{\circ} \mathrm{C}$. Helium was the carrier gas at a constant flow rate of $1 \mathrm{ml} / \mathrm{min}$. $n$-alkanes were then identified and quantified by measuring the areas of their peaks on the $\mathrm{m} / \mathrm{z}$ $57+71+85$ ions specific chromatograms. These areas were converted to areas on the Total Ion Current chromatogram using a correction factor and normalized to the peak of standard and weight of dry sample extracted.

\subsection{Compound-specific isotopic compositions $\left(\delta^{13} \mathrm{C}\right.$ and $\left.\delta^{2} \mathrm{H}\right)$}

The carbon isotopic composition $\left(\delta^{13} \mathrm{C}\right)$ and the hydrogen isotopic composition $\left(\delta^{2} \mathrm{H}\right)$ of the $n-\mathrm{C}_{27}$ and $n-\mathrm{C}_{29}$ alkanes were determined by gas chromatography-isotope ratio mass spectrometry (GC-irMS) using a Trace GC chromatograph 


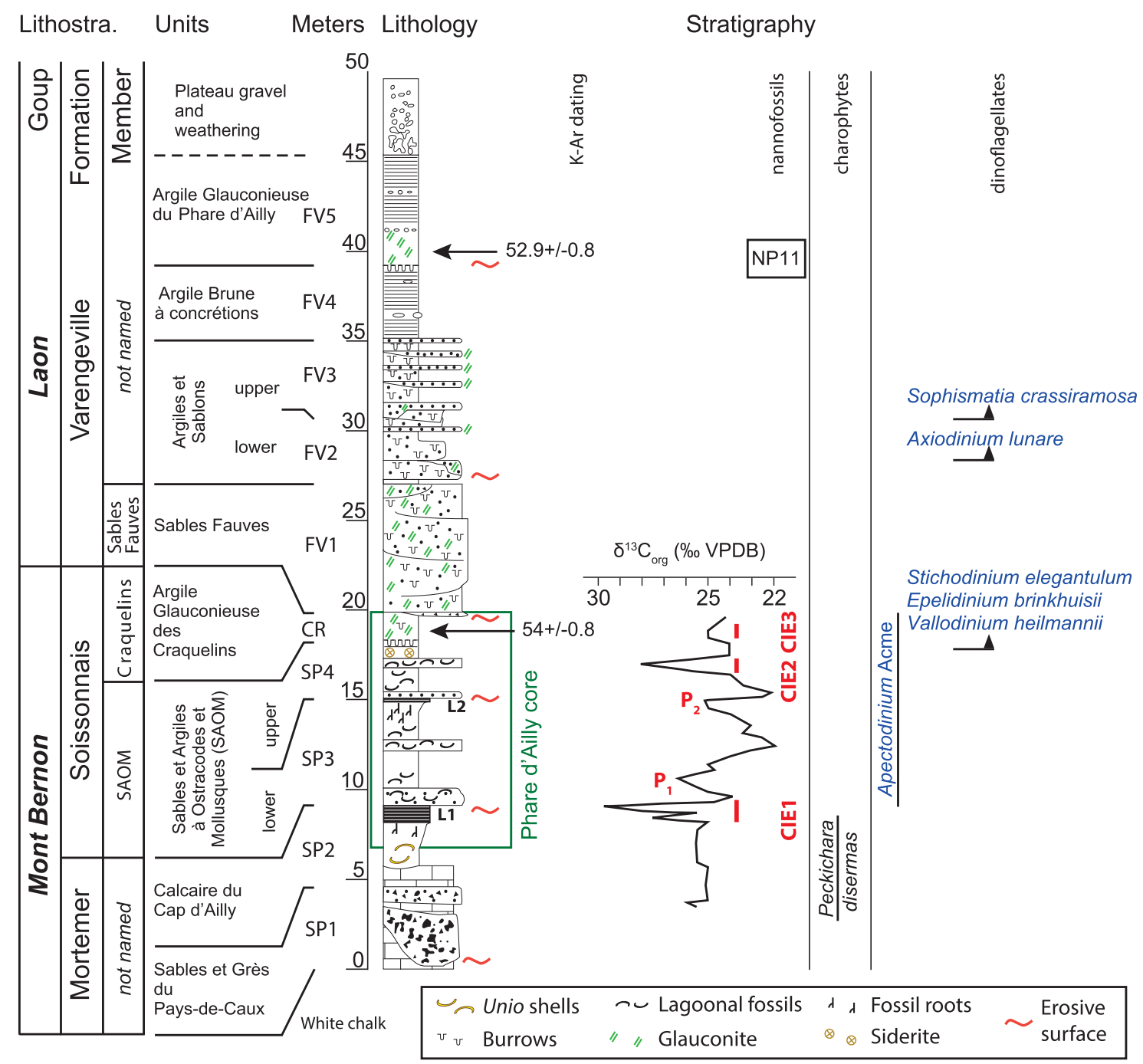

Fig. 2. lithology of the Cap d'Ailly composite section, compared to published $\delta^{13} \mathrm{C}_{\mathrm{org}}$ (Magioncalda, 2004), dinoflagellate (Iakovleva, 2016), nannoplankton (Aubry, 1983) and charophyte (Aubry et al., 2005) data along with K-Ar absolute ages on authigenic glauconite (this work). CIE (carbon isotope excursions) 1 to 3 and $\mathrm{P}_{1}$ and $\mathrm{P}_{2}$ correspond to negative $\delta^{13} \mathrm{C}$ excursions and peaks unraveled by Magioncalda, (2004). Green rectangle: interval spanned by the Phare d'Ailly core studied here. L1 and L2: lignite complex 1 and 2.

equipped with a TriPlus autosampler, connected to a GCisolink combustion (for $\delta^{13} \mathrm{C}$ ) or pyrolysis (for $\delta^{2} \mathrm{H}$ ) interface. Operating conditions were the same as those described in Garel et al. (2013). All $\delta^{13} \mathrm{C}$ values were determined at least in duplicate and $\delta^{2} \mathrm{H}$ in triplicate. They were averaged to obtain a mean value, and normalized to the VPDB and VSMOW scales, respectively.

\subsection{Palynofacies}

Thirty-three samples were manually crushed and treated with $\mathrm{HCl}$ and $\mathrm{HF}$ to remove the mineral matrix. Palynofacies observations were performed using an Axioplan2 Imaging Zeiss microscope under transmitted light and UV excitation (Zeiss HBO 100 Microscope Illuminating System, mercury short-arc lamp) with a magnification of 630. Organic facies were examined, and approximatively 2000 surface units per sample were counted and classified according to the methods of Tyson (1995) and Batten (1996) later modified by Garel et al. (2013).

\subsection{K-Ar measurements}

Two units containing abundant glauconite grains, CR and FV5, were found relevant for pertinent radiometric dating. Glauconite grains are embedded in the clay matrix or concentrated in autochthonous bioturbations, suggesting that they formed in situ. In addition, diverse steps of glauconitization from Fe-illite to mature glauconite were recorded during the preparation of the samples, which also point to an in situ contemporaneous origin. K-Ar dating was carried out on two samples of glauconite grains: 1) sample GL-CRA from the Craquelins Mb, and 2) sample GL-92A64 from the FV5 unit.

About $1.5 \mathrm{~g}$ of grains of glauconite was isolated following the procedure recommended by Odin and Matter (1981). The sediment was first washed with triple distilled water and dried 


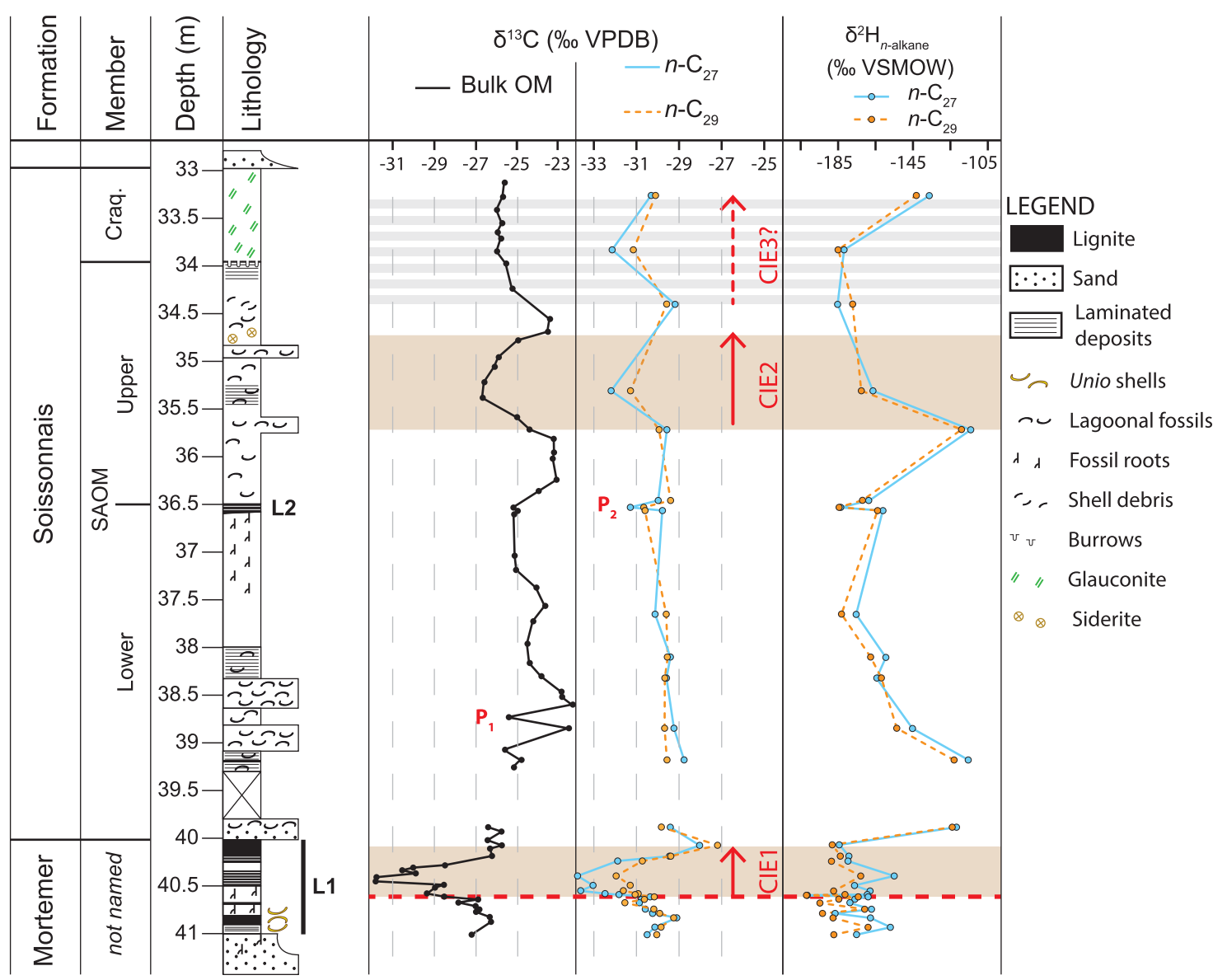

Fig. 3. Phare d'Ailly core lithology compared to the $\delta^{13} \mathrm{C}$ of bulk $\mathrm{OM}$ and $n$-alkane $\mathrm{C}_{27}$ and $\mathrm{C}_{29} \delta^{13} \mathrm{C}$ and $\delta^{2} \mathrm{H}$ isotopic composition. Shaded areas: extension of CIE 1 and 2 and a possible CIE3. See Figure 2 for Peaks $\mathrm{P}_{1}$ and $\mathrm{P}_{2}$. Pal. = Paleocene.

at $45^{\circ} \mathrm{C}$. The sediment was then sieved at 210 and $420 \mu \mathrm{m}$. The separation of glauconite grains in the granulometric fraction between 210 and $420 \mu \mathrm{m}$ was performed using a Frantz magnetizer (intensity of $0.5 \mathrm{~A}$ and tilt of $9^{\circ}$ ). The final purification was achieved under an optical microscope by hand picking the remaining impurities. Then, the grains of glauconite underwent ultrasonic cleaning $(30 \mathrm{~s}$ for the first step and 2 minutes for the second step) to clean the cracks developed during the growth of glauconite grains.

The isotopic composition and abundance of $\mathrm{Ar}$ were determined at the LSCE ("Laboratoire des Sciences du Climat et de l'Environnement", Gif/Yvette, France), using an unspiked technique described by Charbit et al. (1998). The mass spectrometer sensitivity is $5.7 \times 10^{-3} \mathrm{~mol} / \mathrm{A} \Omega \mathrm{m} / \mathrm{e}=40$ with amplifier backgrounds of $75 \times 10^{-12} \mathrm{~A} \Omega \mathrm{m} / \mathrm{e}=40\left(10^{9}\right.$ $\mathrm{ohm}$ resistor $)$, and $5.7510^{-14} \mathrm{~A} \Omega \mathrm{m} / \mathrm{e}=36\left(10^{11} \mathrm{ohm}\right.$ resistor).

Replicate unspiked K-Ar age determinations were done on both samples. Argon was extracted by radio frequency heating of $0.4-0.7 \mathrm{~g}$ of sample, then transferred to an ultra-highvacuum glass line and purified with titanium sponge and $\mathrm{Zr}-\mathrm{Ar}$ getters. Isotopic analyses were performed on total ${ }^{40} \mathrm{Ar}$ contents ranging between 1.0 and $1.5 \times 10^{-9}$ moles using a $180^{\circ}, 6 \mathrm{~cm}$ radius mass spectrometer with an accelerating potential of $620 \mathrm{~V}$. The spectrometer was operated in static mode, but its volume was varied to give equal ${ }^{40} \mathrm{Ar}$ signals for the air aliquots and the samples. Beam sizes were measured simultaneously on a double Faraday collector in sets of 100 online acquisitions with a $1 \mathrm{~s}$ integration time. The atmospheric correction was monitored via a separate measurement of a manometrically-calibrated dose of atmospheric argon for each sample (from a separate reservoir of known ${ }^{40} \mathrm{Ar}$ content). Periodic cross-calibration of zero-age standards precisely constrained the mass-discrimination to within $\pm 0.5 \%$ on the ${ }^{40} \mathrm{Ar} /{ }^{36} \mathrm{Ar}$ ratios.

The manometric calibration of the Air reference is based on periodic, replicate determinations of international dating standards of known $\mathrm{K}-\mathrm{Ar}$ age using the same procedure for the unknowns as described in Charbit et al. (1998). This allows the total ${ }^{40} \mathrm{Ar}$ content of the sample to be determined with a precision of about $\pm 0.2 \%(2 \sigma)$. Standards used include LP-6 $(127.8 \pm 0.7 \mathrm{Ma}$, Odin, 1982) and HD-B1 $-24.21 \pm 0.32 \mathrm{Ma}$ (Hautmann and Lippolt, 2000 and references herein). At the 95\% confidence level, the values adopted here are consistent with those obtained for several ${ }^{40} \mathrm{Ar} /{ }^{39} \mathrm{Ar}$ standards through the intercalibration against biotite GA-1550 by Renne et al. (1998) and Spell and McDougall (2003). Uncertainties for the K and Ar data are $1 \sigma$ analytical only and consist of propagated and quadratically averaged experimental uncertainties arising from the $\mathrm{K},{ }^{40} \mathrm{Ar}$ (total), and ${ }^{40} \mathrm{Ar} *$ determinations. 


\section{Results}

\section{$3.1 \delta^{13} \mathrm{C}$ values of bulk OM and $n$-alkanes}

Bulk OM is enriched in ${ }^{13} \mathrm{C}$ compared to $n-\mathrm{C}_{27}$ and $n$ - $\mathrm{C}_{29}$ alkanes over the record, with $\delta^{13} \mathrm{C}$ values ranging from $-22.3 \%$ to $-31.8 \%$, from $-28 \%$ to $-33.8 \%$ and from $-27.2 \%$ to $-31.9 \%$, respectively. The lowest ${ }^{13} \mathrm{C}$ values are found within the L1 complex (Fig. 3), whereas the highest ones are found at the top of L1 for $n$-alkanes and within the SAOM base for bulk OM. Three negative excursions are observed in all curves: (i) the CIE1 located within the L1 between 40.6 and $40.2 \mathrm{~m}$, with an amplitude of $5 \%$, $4 \%$ and $3 \%$ for bulk OM, $n-\mathrm{C}_{27}$ and $n-\mathrm{C}_{29}$ respectively; (ii) the CIE2 located within the upper SAOM between 35.72 and $34.7 \mathrm{~m}$, with an amplitude of $3.5 \%, 2.2 \%$ and $1.4 \%$ for bulk OM, $n-\mathrm{C}_{27}$ and $n-\mathrm{C}_{29}$ respectively; and (iii) the CIE3 within the Craquelins $\mathrm{Mb}$ (up to $33.3 \mathrm{~m}$ ), which may begin in the uppermost $\operatorname{SAOM}(34.4 \mathrm{~m})$, with an amplitude of $2.5 \%$, $3 \%$ and $2.5 \%$ for bulk OM, $n-\mathrm{C}_{27}$ and $n-\mathrm{C}_{29}$. These three CIEs were first unraveled by Magioncalda (2004) in the Cap d'Ailly section, where they are recorded in the same stratigraphic units. Two additional negative peaks (i.e. with a lower vertical extension compared to CIEs) are also observed: $\mathrm{P}_{1}$ in the lower SAOM (38.75 m) with a magnitude of $2.9 \%$ that is not observed in $n$-alkanes $\delta^{13} \mathrm{C}$ values due to the lower resolution of GC-irMS analyses in this interval; and $\mathrm{P}_{2}$ in the paleosol and L2 complex at the top of the lower SAOM $(36.55 \mathrm{~m})$ with a magnitude of $2 \%, 1.3 \%$ o and $3 \%$ for bulk OM, $n-\mathrm{C}_{27}$ and $n-\mathrm{C}_{29}$ respectively. These two peaks were also observed by Magioncalda (2004) in the Cap d'Ailly section (Fig. 2).

\subsection{Palynofacies}

Three main OM groups are observed (Fig. 4): (i) gelified OM corresponding to plant tissues that suffered gelification (Batten, 1996); (ii) amorphous OM with a strong green fluorescence that has a freshwater algal origin in the Cap d'Ailly area (Garel et al., 2013); and (iii) diffuse non-fluorescent amorphous OM corresponding to degraded OM from various sources. Three kinds of plant debris are also seen: brown wood, opaque and translucid phytoclasts. Furthermore, marine dinocysts and freshwater Chlorococcale algae Pediastrum (family: Hydrodictyaceae) are also found in abundance. OM groups with low relative proportions, such as spore/pollen and opaque phytoclasts are not discussed here (see Supplementary Data).

In the Phare d'Ailly core, the lignite complexes L1 and L2 are dominated by gelified OM (i.e. $>50 \%$ ), except for three samples of the L1 where degraded OM is dominant (Fig. 5). SAOM and Craquelins samples are dominated by degraded OM except for one sample where gelified particles are dominant. Algal amorphous OM displays relative proportions up to $30 \%$, the highest proportions occurring in CIEs 1 and 2 intervals, whereas the lowest proportions are encountered in the SAOM and Craquelins Mbs. Pediastrum algae show very high concentrations in CIEs 1 and 2 intervals (up to 20\%), whereas they only display low to very low concentrations in other samples. Finally, dinocysts that are first encountered in the L1 summit display two intervals of strong concentrations: the first at the base of the SAOM Mb, the second beginning just above the L2 and extending to the base of CIE2.

\subsection{Higher plant $n$-alkanes}

The $n$-alkane distribution in the studied samples shows a dominance of long-chain leaf-wax $n$-alkanes. Their average chain length (ACL) can be calculated using the following equation (where $C_{x}$ refers to the peak area of the individual alkane):

$\mathrm{ACL}=\left(25 \times \mathrm{C}_{25}+27 \times \mathrm{C}_{27}+29 \times \mathrm{C}_{29}+31 \times \mathrm{C}_{31}+\right.$ $\left.33 \times \mathrm{C}_{33}+35 \times \mathrm{C}_{35}\right) /\left(\mathrm{C}_{25}+\mathrm{C}_{27}+\mathrm{C}_{29}+\mathrm{C}_{31}+\mathrm{C}_{33}+\mathrm{C}_{35}\right)$

ACL values range between 28 and 29.2 (Fig. 5). The highest values $(>29)$ are found at the base of the core, just below the CIE1 and within the lower SAOM, whereas the lowest ones are associated with CIE1, CIE2 and the isotopic peak $\mathrm{P}_{2}$.

Previous studies on $n$-alkane distribution revealed a clear relationship between the climate, especially moisture in the environment, and its related type of vegetation and the ACL ( $e$. g. Schwark et al., 2002; Rommerskirchen et al., 2003; Eley and Hren, 2018). Indeed, it appears that $n$-alkanes from vegetation growing under favorable climatic conditions (i.e. temperate or equatorial) display lower ACL values, whereas $n$-alkanes from plants subjected to harsh conditions (i.e. arid or boreal) show a higher ACL. Therefore, this proxy can be used as a complementary tool to decipher paleoclimatic conditions, and, in particular, paleohydrology.

\section{$3.4 \delta^{2} \mathrm{H}$ values of $n$-alkanes}

Along the Phare d'Ailly core, similar trends are observed for the $\delta^{2} \mathrm{H}$ values of both $\mathrm{C}_{27}$ and $\mathrm{C}_{29} n$-alkanes, $n$ - $\mathrm{C}_{29}$ being generally more depleted in ${ }^{2} \mathrm{H}$ (Fig. 3 ). $\delta^{2} \mathrm{H}$ values range between $-114 \%$ and $-202 \%$ for the $n-\mathrm{C}_{27}$ and between $-119 \%$ and $-202 \%$ for the $n-\mathrm{C}_{29}$. The lowest values are observed below the CIE1 and the highest just below CIE2. The CIE1 and the interval immediately below are marked by high frequency changes in $\delta^{2} \mathrm{H}$ values of both $n$-alkanes. In the lower SAOM a less negative peak precedes a decreasing trend that ends at the lignite complex L2 where $n$-alkanes $\delta^{2} \mathrm{H}$ values reach $-185 \%$. Above the maximum peak, $\delta^{2} \mathrm{H}$ values are around $-180 \%$ until the top of the Craquelins $\mathrm{Mb}$ where a less negative peak is observed.

\subsection{Radiometric K-Ar ages on glauconite}

$\mathrm{K}$-Ar datings are given in Table 1. The K-Ar ages of the replicates of the sample GL-CRA are $54.4 \pm 0.8 \mathrm{Ma}$ and $53.6 \pm 0.8 \mathrm{Ma}$; the K-Ar ages of the replicates of the sample GL-92A64 are $53.1 \pm 0.8 \mathrm{Ma}$ and $52.8 \pm 0.7 \mathrm{Ma}$. Altogether, these data show very consistent ages of $54.0 \pm 0.8 \mathrm{Ma}$ and $52.95 \pm 0.8$, respectively. The $\mathrm{K}_{2} \mathrm{O}$ content of the GL-CRA is $5.71 \%$ and $6.63 \%$ for GL-92A64.

\section{Discussion}

\subsection{Reliability of the carbon isotopic data as stratigraphic marker}

The negative carbon isotope excursions of the early Eocene hyperthermals are recorded in both carbonates and sedimentary organic matter (Magioncalda et al., 2004; Krishnan et al., 2014). 

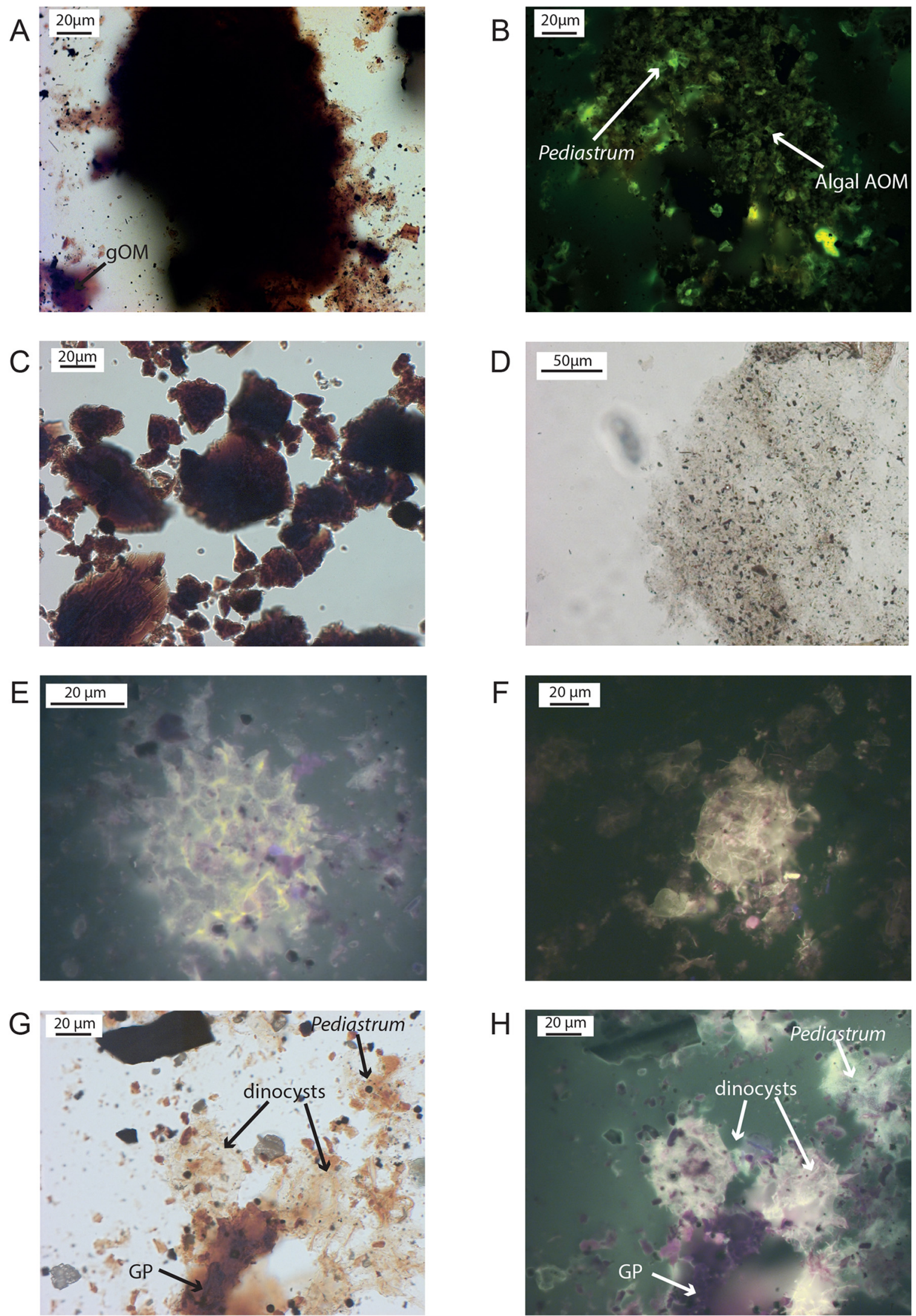

Fig. 4. Palynofacies main categories: (A and B) algal amorphous organic matter under transmitted light and UV respectively; (C) gelified organic matter; (D) diffuse amorphous organic matter; (E) a Pediastrum algae under UV; (F) a dinoflagellate cyst under UV; (G and F) dinocysts, Pediastrum algae and a gelified phytoclast (GP) under transmitted light and UV respectively. 


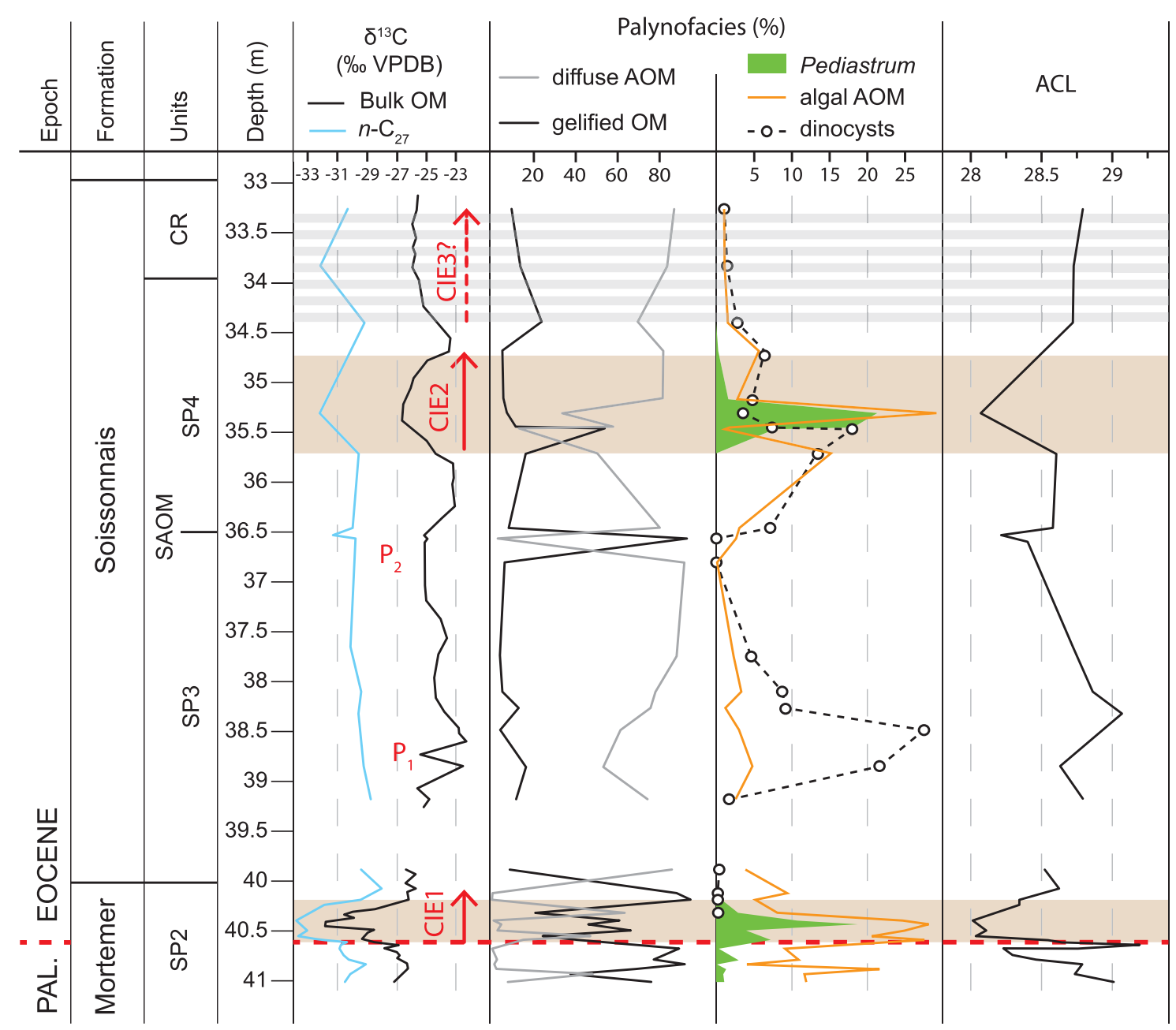

Fig. 5. Phare d'Ailly core palynofacies results and $n$-alkanes ACL (average chain length) values in comparison with $\delta^{13} \mathrm{C}$ curves.

Table 1. K-Ar ages of glauconites. Age calculations are based on the decay and abundance constants from Steiger and Jäger (1977). Analyzed grains were in situ unweathered glauconite without contamination of micas.

\begin{tabular}{lllllll}
\hline Sample number & Lab. sample & Weight molten $(\mathrm{g})$ & $\mathrm{K}_{2} \mathrm{O}(\mathrm{wt} . \%)$ & ${ }^{40} \mathrm{Ar}^{*}(\%)$ & ${ }^{40} \mathrm{Ar}^{*}\left(10^{14} \mathrm{at} / \mathrm{g}\right)$ & $\mathrm{Age} \pm 2(\mathrm{Ma})$ \\
\hline GL-CRA (I) & lab 1658 & 0.02117 & 5.730 & 71.05 & 2.744 & $54.4 \pm 0.8$ \\
GL-CRA (II) & lab 1659 & 0.02226 & 5.730 & 67.47 & 2.696 & $53.6 \pm 0.8$ \\
GL92-A64 (I) & lab 1666 & 0.03230 & 6.630 & 81.75 & 3.095 & $53.1 \pm 0.8$ \\
GL92-A64 (II) & lab 1672 & 0.02226 & 6.630 & 78.33 & 3.121 & $52.8 \pm 0.7$ \\
\hline
\end{tabular}

$\delta^{13} \mathrm{C}_{\mathrm{org}}$ value mainly depends on the source of bulk organic matter (e.g. algae, bacteria and/or land plants) and the $\delta^{13} \mathrm{C}$ value of atmospheric $\mathrm{CO}_{2}$, but is also controlled by several minor factors (for more details see Tyson, 1995 and Meyers, 1997) including: the water temperature during algae biosynthesis and local environmental parameters (e.g. moisture and luminosity). As demonstrated by previous studies (Magioncalda et al., 2001; Garel et al., 2013), the Cap d'Ailly area was marked by important changes in $\mathrm{OM}$ sources during the late Paleocene and the early Eocene. It is thus necessary to decipher whether or not the $\delta^{13} \mathrm{C}_{\mathrm{org}}$ peaks and excursions are mainly linked with changes in $\mathrm{OM}$ sources before using them as reliable chemostratigraphic markers. This is why the $\delta^{13} \mathrm{C}$ values of long-chain $n$-alkanes are precious as they are mainly derived from higher plant leaf waxes (Eglinton and Hamilton, 1967), and thus not affected by changes of OM sources.

First, palynofacies results have shown that the Mortemer Fm is dominated by higher plant (i.e. gelified $\mathrm{OM}$ ) and/or freshwater algae OM (i.e. algal AOM + Pediastrum spp.) whereas the Soissonnais Fm is mainly dominated by marine $\mathrm{OM}$ (i.e. diffuse $\mathrm{AOM}+$ dinocysts). Previous authors have shown that marine algae display a higher $\delta^{13} \mathrm{C}(\approx-26$ to $-20 \%$ ) compared to $C_{3}$ plants $(\approx-32$ to $-23 \%)$ and freshwater algae $(\approx-30$ to $-25 \%$; Tyson, 1995; Meyers, 1997). This would explain the fact that, in the Soissonnais Fm., $\delta^{13} \mathrm{C}_{\text {org }}$ values are $\approx 1.5 \%$ higher than in the $\mathrm{L} 1$, whereas the 


\section{Geologic Time Scale 2012}

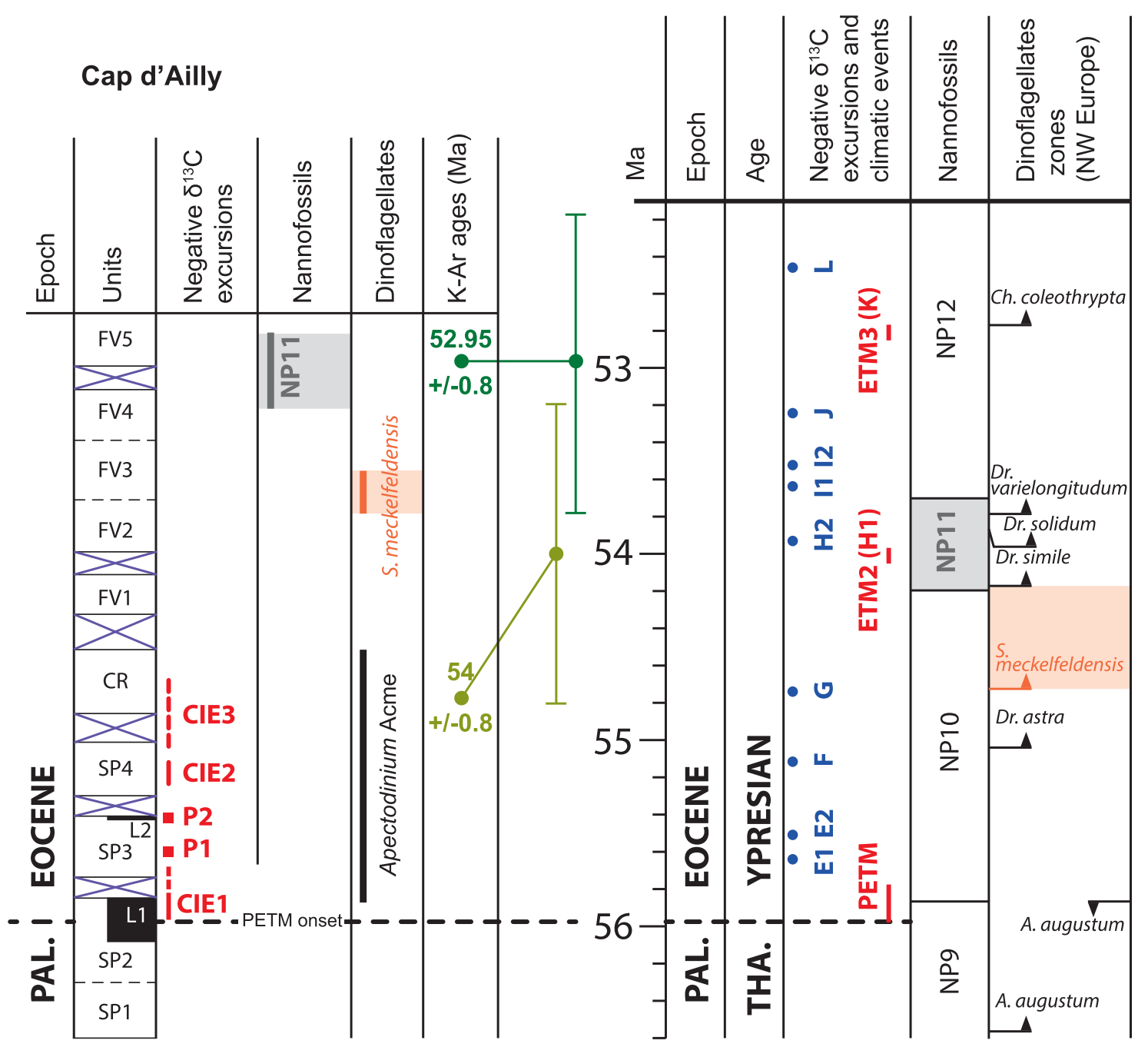

Fig. 6. Tentative correlations between the Cap d'Ailly stratigraphic units (not at scale) and the International chronostratigraphic chart (Vandenberghe et al., 2012), and $\delta^{13} \mathrm{C}$ isotopic excursions ages (Cramer at al., 2003; Westerhold et al., 2017). It shows that negative isotopic excursions (CIE1 and CIE2) and peaks $\left(\mathrm{P}_{1}\right.$ and $\left.\mathrm{P}_{2}\right)$ are older than the $S$. meckelfendense dinoflagellate biozone and thus than ETM2. This is based on nannoplankton (grey box, Aubry, 1983) and dinoflagellate (orange box, Iakovleva, 2016) records, $\mathrm{K}$-Ar glauconite ages and the $\delta^{13} \mathrm{C}$ record (this work). Purple crosses between units indicate an unconformable boundary. The $S$. meckelfeldensis dinoflagellate biozone interval (orange box) is deduced from the first occurence of A. lunare (Iakovleva, 2016). Dinoflagellate first and last occurences are from Vandenberghe et al. (2012) latter modified by Iakovleva (2016). Pal. = Paleocene. Tha. $=$ Thanetian.

$\delta^{13} \mathrm{C}_{n \text {-alkanes values are stable. Thus, it would be hazardous to }}$ compare L1 $\delta^{13} \mathrm{C}_{\text {org }}$ values with the ones of the SAOM and Craquelins Members.

In Phare d'Ailly, CIE1 and CIE2 initiations are both correlated with an increase in freshwater algae concentrations (Fig. 5). Furthermore, the CIE2 initiation is also correlated with strong dinocysts concentrations. However, as both these CIEs are also seen in the $\delta^{13} \mathrm{C}$ curves of longchain $n$-alkanes, it is unlikely that they are only related to a change of source of OM. Furthermore, the curve showing the highest magnitude for every CIE is systematically the $\delta^{13} C_{\text {org }}$ one. This suggests that the increase in freshwater algal OM associated with these excursions has led to a stronger drop of $\delta^{13} \mathrm{C}$ values in the bulk OM than in the longchain $n$-alkanes.
Regarding CIE2, one could argue that it is only validated by one $\delta^{13} C_{n \text {-alkanes sample and that the main part of CIE2 }}$ observed in $\delta^{13} \mathrm{C}_{\text {org }}$ values is linked with the change of OM sources stated above. But this seems very unlikely as, above the peak of freshwater algae concentration, the $\delta^{13} \mathrm{C}_{\text {org }}$ values are still lower than the pre-CIE2 ones. This implies that, the switch from a bulk OM dominated by freshwater algae to a bulk OM dominated by marine OM only had limited effect on the $\delta^{13} \mathrm{C}_{\text {org }}$ values. Thus, the CIE2 is very likely caused by regional/global factors and that it can be used to establish a stratigraphic framework.

Palynofacies results show that there is no change in $\mathrm{OM}$ sources correlated with CIE3. Furthermore, $\delta^{13} \mathrm{C}_{n \text {-alkanes }}$ values also show a decrease in the Craquelins $\mathrm{Mb}$. This suggests that CIE3 is also linked with regional and/or global 
changes. A higher resolution in the $\delta^{13} \mathrm{C}_{n \text {-alkanes }}$ record would however help to have a more accurate magnitude and extent of this excursion.

In Phare d'Ailly, the $\mathrm{P}_{1}$ negative peak is only seen in the $\delta{ }^{13} \mathrm{C}_{\text {org }}$ curve and is correlated to a peak of dinocyst concentrations ( $>20 \%$; Fig. 5). A previous study has shown that organic dinocysts from the late Paleocene and the PETM display $\delta{ }^{13} \mathrm{C}$ values between -27 and $-20 \%$ (Sluijs et al., 2018), a range of values comparable to the one of marine algae ( $\approx-26$ to $-20 \%$; Tyson, 1995; Meyers, 1997). It is thus unlikely that an increase in dinocysts concentrations would cause a negative peak in $\delta^{13} \mathrm{C}_{\text {org }}$ values of the lagoonal SAOM $\mathrm{Mb}$. Furthermore, the $\mathrm{P}_{1}$ negative peak has a wider extension in the Cap d'Ailly section (Fig. 2). Therefore, it is likely that this peak is not an artifact but reflects regional or global changes.

The $\mathrm{P}_{2}$ negative peak initiation is not associated with changes in organic sources (Fig. 5). Its lower magnitude in the $\delta^{13} \mathrm{C}_{n \text {-alkanes }}$ curve is likely due to the fact that the sample with the pre- $\mathrm{P}_{2}$ highest $\delta^{13} \mathrm{C}_{\text {org }}$ value (at $-37.58 \mathrm{~m}$ ) was not analyzed with a GC-irMS. A higher resolution in the $\delta^{13} C_{n-}$ alkanes record would thus help to accurately determine the magnitude and extent of this peak.

It thus seems that all these negative peaks and excursions are not related to changes in OM sources. This implies that they are linked with regional/global factors and that they can be used as stratigraphic markers, at least in the Paleocene-Eocene sites of the region.

\subsection{Litho- Bio- and Chemo-stratigraphy, and K-Ar dating}

$\mathrm{K}-\mathrm{Ar}$ dating methods on glauconite grains have been widely used to date sedimentary successions (see a synthesis in Clauer et al., 2005). The $\mathrm{K}_{2} \mathrm{O}$ contents of the samples are close to or higher than $6 \%$, suggesting that the grains of glauconite have a sufficient degree of evolution to provide reliable $\mathrm{K}-\mathrm{Ar}$ dating (Odin and Matter, 1981). All these data show ages younger than the age of the P-Eb (55.93 Ma; Westerhold et al., 2018) and also younger than the end of the PETM interval ( 200 ka after P-Eb; Murphy et al., 2010). The age of the lower sample $(54.0 \pm 0.8 \mathrm{Ma})$ is logically older than the age of the upper sample in the succession $(52.95 \pm 0.8)$, suggesting an evolution in the formation of glauconite grains of the two studied samples.

Biostratigraphically, the lowermost Sparnacian sediments of the Cap d'Ailly area (i.e. units SP1 and SP2; Fig. 2) are within the Peckichara disermas charophyte biozone that is correlative to the NP9 nannoplankton biozone (Magioncalda et al., 2001; Aubry et al., 2005). Furthermore, previous isotopic studies on organic matter in other Cap d'Ailly sites located the P-Eb and the CIE of the PETM in the Lignite complex L1 (Magioncalda et al., 2001; Storme et al., 2012; Garel et al., 2013). In the Phare d'Ailly core, the CIE1 is also found in the L1. This indicates that the CIE1 initiation corresponds to the $\mathrm{P}-\mathrm{Eb}$ and that the upper part of the $\mathrm{L} 1$ complex was deposited during the PETM.

In the Varengeville Formation, the presence of Axiodinium lunare and Sophismatia crassiramosa dinoflagellates in the FV2 and FV3 units, respectively (Iakovleva, 2016; Fig. 2), points to the dinocyst biozone Stenodinium meckefeldense
(W. meckefeldensis in Vandenberghe et al., 2012), which is correlated with the upper NP10 nannoplankton biozone (Fig. 6; Vandenberghe et al., 2012). Moreover, in the upper FV4 and lower FV5 units, former studies revealed nannoplankton species corresponding to the NP11 biozone (Aubry, 1983). This is in agreement with the K-Ar age obtained on FV5 glauconite grains (i.e. $53.75 \pm 0.8 \mathrm{Ma}$; Fig. 6), as the NP11 biozone extends from 54.17 to $53.6 \mathrm{Ma}$ (Vandenberghe et al., 2012).

SP3 and SP4 units (i.e. the SAOM Mb) are thus younger than the P-Eb and older than the NP11 biozone (Fig. 6), which is consistent with the $\mathrm{K}-\mathrm{Ar}$ age found in the Craquelins $\mathrm{Mb}$ (i.e. $54 \mathrm{Ma} \pm 0.8)$. The SAOM and Craquelins Members are characterized by an Apectodinium acme (Fig. 6), which would point to a PETM age in the Dieppe-Hampshire Basin (Iakovleva, 2016). However, regarding the Craquelins Mb, a deposition during the PETM is not supported by the glauconite $\mathrm{K}$-Ar ages $(54.0 \pm 0.8 \mathrm{Ma})$ that are, at minima, $\approx 0.93 \mathrm{Ma}$ younger than the end of the PETM $(\approx 55.73 \mathrm{Ma}$; Westerhold et al., 2018).

Considering these data, we can put forward two hypotheses regarding the age of the CIE2, CIE3 and SAOM and Craquelins Members:

- As suggested by the dinoflagellate record (Iakovleva, 2016), the SAOM Member is interpreted to have been deposited during the PETM. This implies that the zigzag shape of the $\delta^{13} \mathrm{C}$ curves between the $\mathrm{P}-\mathrm{Eb}$ and the Varengeville Formation, including CIE2, is the result of local/regional environmental changes. As stated before, the negative peaks and excursions found in the Cap d'Ailly area are not related to varying inputs of terrestrial OM in a lagoonal environment. Thus, if not associated to global causes, a return to pre-PETM $\delta{ }^{13} \mathrm{C}$ values between the two CIEs could only be explained by environmental factors such as a strong decrease in regional moisture, in light exposure, or in available nutrients, and/or by major changes within the local/regional vegetation (Tappert et al., 2013).

- As suggested by the isotopic record of both sites, the CIE2 may represent another isotopic event with an age corresponding to the nannofossil biozone NP10, which excludes ETM-2 and posterior events. As suggested by the cyclostratigraphic study of Cramer et al. (2003) on oceanic sites, the candidates are the E1, E2, F and G events. In the Cap d'Ailly area, the lack of more precise stratigraphic data excludes any refined age. However, if we consider the shape of the $\delta^{13} C_{\text {org }}$ curve at Cap d'Ailly section and in the Phare d'Ailly core (Figs. 2 and 3), the negative carbon isotope peaks $\mathrm{P}_{1}$ and $\mathrm{P}_{2}$ could represent events $\mathrm{E} 1$ and $\mathrm{E} 2$, implying that CIE2 corresponds to the F event. CIE3 could then correspond to the G event, which is in agreement with glauconite $\mathrm{K} / \mathrm{Ar}$ ages (Fig. 6). However, a better resolution of $n$-alkane $\delta^{13} \mathrm{C}$ curves is required to more accurately determine the vertical extension and magnitude of these excursions. Finally, this hypothesis implies that the dinocyst record in the Cap d'Ailly Soissonnais Fm (Iakovleva, 2016), including an Apectodinium acme, is not related to the PETM. This suggests that this specific assemblage is thus a consequence of the relative isolation of the Dieppe-Hampshire Basin during the early Eocene (Dupuis and Thiry, 1998), allowing a different evolution of 
the dinoflagellate population than the one observed in the North Sea. Furthermore, in our area, the Apectodinium acme would only be related to very favorable environmental conditions not necessarily linked with hyperthermal events. Actually, very high percentages of Apectodinium spp. have already been observed in other mid- and highlatitude successions, before and after the PETM (e.g. Sluijs et al., 2005; 2006; 2011; Bijl et al., 2013).

To determine which hypothesis is correct, additional analyses are required such as temperature records to determine the duration of the PETM hyperthermal event in this key area.

\subsection{Early Eocene paleoenvironmental changes}

The L1 lignite complex of the Cap d'Ailly area is thought to have been deposited in a swamp environment that experienced strong environmental changes (Magioncalda et al., 2001; Garel et al., 2013). The strongest change occurred at the P-Eb with an abrupt change in OM distribution (Fig. 5). Indeed, whereas gelified OM dominates Paleocene samples, the CIE1 coincides with peaks of algal OM proportions, including Pediastrum algae. Thus, the P-Eb is marked by a switch from dominant allochthonous higher plant OM inputs to dominant autochthonous aquatic inputs. This suggests an evolution from a marsh pond to a more open and deeper swamp environment, similar to those recorded in Vasterival (France; Garel et al., 2013) and in Cobham (England; Collinson et al., 2007; Inglis et al., 2019). Furthermore, high concentrations in Pediastrum algae are generally associated with eutrophic water environments and strong seasonal nutrient, and thus clastic, inputs (Tyson, 1995). This is also supported by the disappearance of Unio shells in the upper half of the L1 lignite complex in the whole area (Garel et al., 2013), a mollusk that cannot live in environments marked by high detrital inputs (Good, 2004). Therefore, the CIE1 in the Cap d'Ailly area appears to be marked by stronger detrital and nutrient inputs that enabled phytoplankton blooms causing eutrophication of the water column.

The end of CIE1 is encountered at the top of the L1 lignite complex and it coincides with the appearance of dinoflagellate cysts and a decrease in algal OM proportions (Fig. 5). This points to a significant marine influence in the swamp environment (Tyson, 1995) that would have caused a decline of freshwater algae such as Pediastrum, which is stenohaline and cannot sustain significant salinity variations (Tyson, 1995). This marine influence then increases upward, leading to the drowning of peat mires as seen in other localities of NW Europe (Magioncalda et al., 2001; Collinson et al., 2007; Garel et al., 2013; Methner et al., 2019), to eventually allow the setup of a lagoonal environment and the deposition of the SAOM $\mathrm{Mb}$. It has been shown that an increase in salinity results in an increase in higher plant $\delta^{13} \mathrm{C}$ values (Ladd and Sachs, 2013). Thus, the return to less negative $\delta^{13} \mathrm{C}$ values in the uppermost L1 is probably caused by the increasing marine influence, a hypothesis already proposed for the Vasterival section (Garel et al., 2013).

In the lower SAOM Mb, the degraded OM dominates all the samples, thus pointing to a relatively well oxygenated environment (Tyson, 1995) in agreement with the numerous coquinas and tidal sand laminae present in this Member. Moreover, significant dinocyst concentrations of the genus Apectodinium are observed between 39 and $38 \mathrm{~m}$ depth, close to the $\mathrm{P}_{1}$ negative isotopic peak (Fig. 5). These dinoflagellate blooms in coastal areas indicate higher detrital and nutrient inputs (Crouch et al., 2003) compared to the rest of the lower $\mathrm{SAOM} \mathrm{Mb}$.

Above, the lignite complex L2 is characterized by the disappearance of dinocysts and the dominance of gelified OM derived from plants, in agreement with its swamp origin. The upper SAOM and Craquelins Members show a dominance of degraded OM (Fig. 5). The base of the upper SAOM Mb is marked by an increasing trend in dinocyst proportions that ends at the base of CIE2. This trend is accompanied and followed by high concentrations in freshwater algal material including Pediastrum, that diminishes in the second part of CIE2. It is surprising to find such quantities of freshwater material in lagoonal sediments, as indicated by the fauna present in these beds (Dupuis et al., 1998). The presence of such quantities of stenohaline algae can only be explained by extensive freshwater inputs from land that probably impacted the dinoflagellate population. Furthermore, such an abundance in Pediastrum algae also indicates the presence of a eutrophic environment inland, a possible consequence of a climate with stronger seasonality (Tyson, 1995). It thus appears that the onset of CIE2 is linked to strong environmental changes within the lagoonal environment of the Cap d'Ailly area, with dinoflagellate blooms and extensive freshwater inputs, but also on land with eutrophication and algal blooms in the catchment area linked to the lagoon.

Finally, no evidence of strong environmental changes was found within the CIE3 interval. However, as the distance from the coast and depth increased at the end of the Soissonnais Fm (Dupuis et al., 1998), it is less likely to record changes that occurred on land.

\subsection{Paleohydrological changes}

\subsubsection{Factors controlling terrestrial $n$-alkane $\delta^{2} \mathrm{H}$ values}

The hydrogen isotopic composition $\left(\delta^{2} \mathrm{H}\right)$ of higher plant leaf wax $n$-alkanes is mainly impacted by the $\delta^{2} \mathrm{H}$ of meteoric waters, which itself depends on the amount of precipitation, the temperature at the precipitation site and the source of humidity (Sachse et al., 2012). It is also affected by the degree of leafwater transpiration and soil-water evaporation that depend on climatic parameters, and by interspecific variability, which is linked to the plant physiology and biochemistry (Smith and Freeman, 2006). However, previous studies on the paleovegetation of the Cap d'Ailly area revealed no correlation between vegetation changes and $n$-alkane $\delta^{2} \mathrm{H}$ values, implying that the latter are mostly linked to paleoclimatic changes and not to changes in vegetation (Garel-Laurin, 2013; Garel et al., 2014). Furthermore, Garel et al. (2013) produced $\delta^{2} \mathrm{H}$ values of onocerane I, a biomarker considered specific to a limited number of angiosperm species (Jacob et al., 2004). Thus, onocerane I $\delta^{2} \mathrm{H}$ values are very unlikely affected by vegetation changes and probably only controlled by paleohydrological parameters. $\delta^{2} \mathrm{H}_{\text {onocerane I values display a similar }}$ trend as that of $\delta^{2} \mathrm{H}_{n \text {-alkane }}$ ones, implying that these later are also representative of paleohydrological changes and almost 
not affected by vegetation changes Regarding these data and the proximity of these two sites, we consider that Phare d'Ailly $\delta^{2} \mathrm{H}_{n \text {-alkanes }}$ changes are also mostly linked with paleohydrological variations.

In the Phare d'Ailly core, $\delta^{2} \mathrm{H}$ values range from -202 to $-114 \%$ for $\mathrm{C}_{27} n$-alkane and from -202 to $-119 \%$ for $\mathrm{C}_{29} n$ alkane (Fig. 3). In the lignite complex L1, $n$-alkanes $\delta^{2} \mathrm{H}$ values display similar magnitudes to those found in the Vasterival section (Garel et al., 2013), also located in the Cap d'Ailly area. Yet, these values are lower $(\approx 20 \%)$ in Phare d'Ailly than in Vasterival. It is unlikely that such close locations displayed different climate and/or distance from the precipitation site. Thus, it is probable that these differences in $\delta^{2} \mathrm{H}$ values are linked to a greater water availability for plants in the surroundings of the Phare d'Ailly depositional environment compared to the Vasterival one. This hypothesis is strengthened by sedimentological evidence pointing to a more restricted environment in Vasterival during the L1 deposition, such as the presence of bacterial-induced carbonate nodules that can only form within sediments of very restricted swamp environments (Garel et al., 2013).

A previous study has proposed a way to calculate the $\delta^{2} \mathrm{H}$ of precipitations based on long chain $n$-alkanes $\delta^{2} \mathrm{H}$ (e.g. Sachse et al., 2012). In this study, a mean fractionation value between $n-\mathrm{C}_{29}$ and mean annual precipitation (MAP) $\delta^{2} \mathrm{H}$ values for major taxonomic categories of modern plant (e.g. $\mathrm{C}_{3}$ angiosperms, Pteridophytes and $\mathrm{C}_{3}$ gymnosperms). Garel et al. (2014) have shown that the Cap d'Ailly Sparnacian vegetation was mostly dominated by angiosperms. So, we can apply the mean fractionation value between $n-\mathrm{C}_{29}$ of $\mathrm{C}_{3}$ angiosperms and MAP $\left(\varepsilon_{\mathrm{C} 29 / \mathrm{MAP}}\right)$, which is $-110 \%$ (Sachse et al., 2012). $\delta^{2} \mathrm{H}$ precipitation values for the Phare d'Ailly site are given in the supplementary data. They range from -91 to $-9 \%$ with a mean of $-58 \%$ and a median of $69.4 \%$. These values are intermediate between the Eocene ones of Possagno (Italy; 0 to $-34 \%$ ) and Lillebaelt (Denmark; -53 to $-93 \%$ ), which were calculated by Speelman et al. (2010). This is consistent with the intermediate latitudinal position of Cap d'Ailly compared to these two sites.

\subsubsection{Lignite complex L1}

In the Phare d'Ailly core, $n$-alkane $\delta^{2} \mathrm{H}$ curves display a zigzag shape in Upper Paleocene sediments, with variations in magnitudes reaching $25 \%$ (Fig. 3). If strictly interpreted as paleoclimatic changes, these values would indicate perturbations in the hydrological cycle with an alternation of dry and wet conditions (Smith and Freeman, 2006). Such variations were also found in the Vasterival section (Garel et al., 2013), thus strengthening a regional climatic cause for these environmental changes. Evidence of climatic changes at the end of the Paleocene has already been reported in several locations, such as in the London Basin (England) where evidence of increased seasonality has been observed (Collinson et al., 2007). These Upper Paleocene climatic changes were probably related to an intense episode of volcanic activity in the North Atlantic Igneous Province, maybe linked to the beginning of stage 2 described in Abdelmalak et al. (2016). This stronger volcanic activity would have led to an increase in atmospheric $\mathrm{CO}_{2}$ concentrations, and thus to a progressive climate change.
In our site, the $\mathrm{P}-\mathrm{Eb}$ is marked by a $30 \%{ }^{2} \mathrm{H}$ depletion of $n$ alkanes, suggesting moister conditions (Smith and Freeman, 2006). The magnitudes of $n$-alkane $\delta^{2} \mathrm{H}$ variations at the $\mathrm{P}-\mathrm{Eb}$ are stronger in Vasterival $(\approx 60 \%$ ) compared to Phare d'Ailly $(\approx 30 \%$ ). This difference is likely due to a greater water availability in Phare d'Ailly compared to Vasterival, as stated above. The ${ }^{2} \mathrm{H}$ depletion of $n$-alkanes at the P-Eb is followed by a ${ }^{2} \mathrm{H}$ enrichment that leads to $n$-alkane $\delta^{2} \mathrm{H}$ values comparable to the pre-PETM ones (Fig. 3), and points to slightly drier conditions than before. However, this change is associated with a decrease in ACL values and an increase in algal OM concentrations, both pointing to overall moister conditions (Tyson, 1995; Rommerskirchen et al., 2003; Eley and Hren, 2018). Furthermore, these algal blooms suggest that the climate was marked by a stronger seasonality (Tyson, 1995), which would explain the apparent discrepancy between $n$-alkanes $\delta^{2} \mathrm{H}$ values and palynofacies data. This agrees with the conclusions of Garel et al. (2013) that pointed to the setup of a moister climate with stronger seasonality in the Cap d'Ailly area at the early PETM. Similar changes seemed to occur in northern Spain (Pujalte et al., 2016), in the North Sea (Kender et al., 2012; Eldrett et al., 2014) and in England (Collinson et al., 2007; Inglis et al., 2019).

\subsubsection{SAOM and Craquelins Members}

The low resolution of samples within the Craquelins $\mathrm{Mb}$ (Figs. 3 and 5) does not make it possible to unravel any paleoenvironmental change associated to the potential CIE3. Thus, this Member will not be discussed in this part.

Regarding the SAOM Mb, it is very likely that the $n$ alkanes analyzed in these sediments are representative of a wider drainage area compared to the ones found in the L1 complex, as this member corresponds to a lagoonal environment that was much more open compared to the swamp that deposited the L1 complex. Thus, $n$-alkane relative proportions and their $\delta^{2} \mathrm{H}$ values reflect paleohydrological conditions (e.g. precipitation amount, moisture and the extent of leaf- and soil-water evaporation) of a much wider area for the SAOM than for the L1. Therefore, it would be hazardous to compare SAOM data with those of the L1 complex.

The lower SAOM unit first shows a $\delta^{2} \mathrm{H}$ peak at $-125 \%$ for both $n$-alkanes followed by a decrease that stops in the L2 complex (Fig. 3), suggesting a progressive change to moister conditions (Smith and Freeman, 2006). The dramatic increase in dinocyst proportions that is observed at the beginning of this trend suggests that the moister conditions on land caused an increase in nutrient inputs into the lagoon, and thus, dinoflagellate blooms (Tyson, 1995).

Above, the first sample in the upper SAOM unit displays $n$ alkane $\delta^{2} \mathrm{H}$ values similar to the last value observed in the lower SAOM Mb (Fig. 3), suggesting a relative stability of hydrological conditions on land (Smith and Freeman, 2006). It is followed by a peak at $-125 \%$ for both $n$-alkanes just below CIE2 that points to drier conditions, followed itself by a return to more negative values in the body of CIE2, and thus moister conditions (Smith and Freeman, 2006). This last sample is also marked by lower ACL values than previously that also point to moister conditions (Eley and Hren, 2018). A similar $\delta^{2} \mathrm{H}$ pattern has been observed in the Arctic around the ETM2 event (Krishnan et al., 2014). For our sites, if we consider the 
hypothesis 2 , the increase in $\delta^{2} \mathrm{H}$ values followed by their increase might be related to a two steps event. This is strengthened by the palynofacies data that display a strong increase in dinocyst concentrations followed by a peak in freshwater algae proportions. As for the PETM, a climatic change in two steps may be linked to a volcanic event triggering a first climatic change but also a series of events such as the release of thermogenic methane (Frieling et al., 2016) eventually causing a hyperthermal event.

In the Phare d'Ailly core, these hydrological changes are correlated with high concentrations of dinocysts and freshwater algae, with Pediastrum species appearing only after the peak of drier conditions (Figs. 3 and 5). They point to the eutrophication of water masses and higher seasonality on land (Tyson, 1995) for an interval ranging from below the CIE2 base to its body. Thus, it appears that the CIE2 coincides with strong climatic changes causing dramatic environmental variations in both terrestrial and lagoonal environments. Such evidence of eutrophication has also been observed in similar sediments of the Kallo borehole (Belgium, Steurbaut et al., 2003), where a second CIE, a few meters above the end of the first CIE, is also correlated with high proportions of Pediastrum algae. This may indicate that CIE2 is linked to a regional event implying environmental eutrophication and a climate with stronger seasonality on land.

Moreover, it has to be noted that this event follows an interval of relative climatic stability (i.e. the lower SAOM unit). To our knowledge, the occurrence of two intervals of dramatic climatic and environmental changes has never been observed for the PETM alone. Moreover, except for CIE2 and L2 samples, the $\delta^{2} \mathrm{H}$ record does not seem correlated to the $\delta{ }^{13} \mathrm{C}$ record, implying that the zigzag shape of the $\delta^{13} \mathrm{C}$ curve is not related to climate variations. Thus, this climatic succession may suggest that CIE1 and CIE2 correspond to two different events: the PETM for CIE1, and the E1, E2, F or G event for CIE2. However, to prove such a hypothesis, temperature proxies are needed to determine whether the whole Soissonnais Fm. is associated with the PETM hyperthermal event or not. In any case, this study shows for the first time either two important different environmental events within the PETM or strong environmental consequences linked with the carbon isotope events E1, E2, F or G.

\section{Conclusions}

New high-resolution organic matter and higher plant $n$ alkanes $\delta{ }^{13} \mathrm{C}$ records along with $\mathrm{K}-\mathrm{Ar}$ ages on glauconite and available stratigraphic data from two sites of the Cap d'Ailly area provide a framework to unravel climatic and environmental changes associated with Lower Eocene hyperthermals and isotopic events. Our results show five negative CIEs, the main ones being CIE1 and CIE2, within terrestrial and coastal sediments of the Sparnacian Mortemer and Soissonnais Formations, which are older than the NP11 nannofossil biozone. While the CIE1 is clearly associated with the PETM, the CIE2 could either correspond to 1) a second excursion within the PETM interval, as suggested by the dinocyst record, implying that less negative $\delta^{13} \mathrm{C}$ values between the two CIEs are related to regional environmental changes or 2) to another global isotopic event, as suggested by $\delta^{13} \mathrm{C}$ values and $\mathrm{K}-\mathrm{Ar}$ ages, which occurred before the ETM2 such as events E1, E2, $\mathrm{F}$ and $\mathrm{G}$. The latter hypothesis implies that the dinocyst record of the Cap d'Ailly area was affected by a different evolution compared to the North Sea, maybe due to relative isolation during this interval. In that case, other negative peaks and excursions recorded in the Cap d'Ailly likely correspond to these events.

Palynofacies observations indicated that both CIEs were associated with dramatic environmental changes, such as eutrophication and algal and/or dinoflagellate blooms. These changes were probably, at least, regional as they were also recorded in the Belgian Basin. Furthermore, higher plant $n$ alkanes relative proportions and $\delta^{2} \mathrm{H}$ records revealed that these intervals are linked to paleohydrological changes and higher seasonality. These data also revealed that the interval just below the CIEs is marked by environmental and paleoclimatic changes, which were already reported in other locations before the PETM and the ETM-2. Thus, our study shows for the first time either 1) a PETM marked by two distinct intervals of dramatic environmental and climatic changes; or 2) that a "minor" isotopic event, E1, E2, F or G, was associated with strong environmental and climatic changes similar to those that occurred around the P-Eb.

Acknowledgements. S.G. thanks the French "Ministère de l'Enseignement Supérieur et de la Recherche" for a Doctoral grant. We wish to thank Florence Savignac (Sorbonne Université) for her technical support, Jean-Yves Storme for scientific discussion, Hervé Guillou for K-Ar analyses and Elizabeth Rowley-Jolivet for English revision. We also thank Vittoria Lauretano and an anonymous reviewer for their comments and reviews, which considerably improved the manuscript. This paper is a contribution to the Research cooperation contract financially supported by the BRGM ("Paléosurface éocène-PETM" research project) and to the BRGM Scientific Programs "Genèse et caractéristiques des Régolithes" and "Référentiel Géologique de la France". The work was part of the PalHydroMil project, supported by Agence Nationale de la Recherche Grant ANR-2010-JCJC607-01. J.Y. thanks the Belgian Science Policy Office, project 688 BR/121/A3/PALEURAFRICA.

\section{References}

Abdelmalak MM, Meyer R, Planke S, et al. 2016. Pre-breakup magmatism on the Vøring Margin: Insight from new sub-basalt imaging and results from Ocean Drilling Program Hole 642E. Tectonophysics 675: 258-274.

Abels HA, Lauretano V, van Yperen AE, et al. 2016. Environmental impact and magnitude of paleosol carbonate carbon isotope excursions marking five early Eocene hyperthermals in the Bighorn Basin, Wyoming. Clim. Past. 12: 1151-1163.

Aubry M-P. 1983. Biostratigraphie du Paléogène épicontinental de l'Europe du Nord-Ouest. Étude fondée sur les nannofossiles calcaires. Docum. Labo Géol. Lyon, 89: 317.

Aubry M-P, Thiry M, Dupuis C, Berggren WA. 2005. The Sparnacian deposits of the Paris Basin: A lithostratigraphic classification. Stratigraphy 2: 65-100.

Batten DJ. 1996. Chapter 26A. Palynofacies and paleoenvironmental interpretation. In: Jansonius J, McGregor DC, eds. Palynology: 
Principles and Applications. American Association of Stratigraphic Palynologists Foundation, pp. 1011-1064.

Bijl PK, Bendle JAP, Bohaty SM, et al. 2013. Eocene cooling linked to early flow across the Tasmanian Gateway. PNAS 110: 9645-9650.

Charbit S, Guillou H, Turpin L. 1998. Cross calibration of K-Ar standard minerals using an unspiked Ar measurement technique. Chem. Geol. 50: 147-159.

Clauer N, Huggett JM, Hillier S. 2005. How reliable is the K-Ar glauconite chronometer? A case study of Eocene sediments from the Isle of Wight. Clay Miner. 40: 167-176.

Coccioni R, Bancalà G, Catanzarit R, et al. 2012. An integrated stratigraphic record of the Palaeocene-lower Eocene at Gubbio (Italy): new insights into the early Palaeogene hyperthermals and carbon isotope excursions. Terra Nova 24: 380-386.

Collinson ME, Steart DC, Scott AC, Glasspool IJ, Hooker JJ. 2007. Episodic fire, runoff and deposition at the Palaeocene-Eocene boundary. J. Geol. Soc., London 164: 87-97.

Cramer BS, Wright JD, Kent DV, Aubry M-P. 2003. Orbital climate forcing of $\delta 13 \mathrm{C}$ excursions in the late Paleocene-early Eocene (chrons C24n-C25n). Paleoceanography 18: 1097.

Crouch EM, Dickens GR, Brinkhuis H, et al. 2003. The Apectodinium acme and terrestrial discharge during the Paleocene-Eocene thermal maximum: new palynological, geochemical and calcareous nannoplankton observations at Tawanui, New Zealand. Palaeogeogr. Palaeoclimatol. Palaeoecol. 194: 387-403.

Dupuis C, Thiry M. 1998. Geological frame of the "Sparnacian". In: Thiry M, Dupuis C, eds. The Paleocene/Eocene boundary in Paris basin: the Sparnacian deposits. Field trip guide. École Nationale Supérieure des Mines de Paris, Mémoire des Sciences de La Terre 34: 3-12.

Dupuis C, Steurbaut E, De Coninck J, Riveline J. 1998. The Western Argiles à Lignites facie. In: Thiry $\mathrm{M}$, Dupuis $\mathrm{C}$, eds. The Paleocene/Eocene boundary in Paris basin: the Sparnacian deposits. Field trip guide. École Nationale Supérieure des Mines de Paris, Mémoire des Sciences de La Terre 34: 60-71.

Eglinton G, Hamilton RJ. 1967. Leaf Epicuticular Waxes. Science 156: $1322-1335$.

Eldrett JS, Greenwood DR, Polling M, Brinkhuis H, Sluijs A, 2014. A seasonality trigger for carbon injection at the Paleocene-Eocene Thermal Maximum. Clim. Past. 10: 759-769.

Eley YL, Hren MT. 2018. Reconstructing vapor pressure deficit from leaf wax lipid molecular distributions. Sci. Rep. UK 8: 3967.

Frieling J, Svensen HH, Planke S, Cramwinckel MJ, Selnes H, Sluijs A. 2016. Thermogenic methane release as a cause for the long duration of the PETM. P. Natl. Acad. Sci. USA 113: 12059-12064.

Garel S, Schnyder J, Jacob J, et al. 2013. Paleohydrological and paleoenvironmental changes recorded in terrestrial sediments of the Paleocene-Eocene boundary (Normandy, France). Palaeogeogr. Palaeoclimatol. Palaeoecol. 376: 184-199.

Garel S, Quesnel F, Jacob J, et al. 2014. High frequency floral changes at the Paleocene-Eocene boundary revealed by comparative biomarker and palynological studies. Org. Geoch. 77: 43-58.

Garel-Laurin S. 2013. Changements paléoenvironnementaux et paléoclimatiques enregistrés dans les faciès continentaux et lagunaires de la limite Paléocène-Eocène des bassins de Paris et de Dieppe-Hampshire. Apports de l'étude de la matière organique. $\mathrm{PhD}$ thesis, Université Pierre et Marie Curie, $448 \mathrm{p}$.

Good SC. 2004. Paleoenvironmental and paleoclimatic significance of freshwater bivalves in the Upper Jurassic Morrison Formation, Western Interior, USA. Sediment. Geol. 167: 163-176.

Hautmann S, Lippolt HJ. 2000. 40Ar/39Ar dating of central European K-Mn oxides - a chronological framework of supergene alteration processes during the Neogene. Chem. Geol. 170: 37-80.
Iakovleva AI. 2016. Did the PETM trigger the first important radiation of wetzelielloideans? Evidence from France and northern Kazakhstan. Palynology 41: 311-338.

Inglis GN, Farnsworth A, Collinson ME, et al. 2019 Terrestrial environmental change across the onset of the PETM and the associated impact on biomarker proxies: A cautionary tale. Glo. Pla. Cha. 181: 102991

Jacob J, Disnar J-R, Boussafir M, et al. 2004. Onocerane attests to dry climatic events during the Quaternary in the tropics. Org. Geoch. 35: 289-297.

Kender S, Stephenson MH, Riding JB, et al. 2012. Marin end terrestrial environmental changes in NW Europe preceding carbon release at the Paleocene-Eocene transition. Earth Planet. Sc. Lett. 353-354: 108-120.

Kennett JP, Stott LD. 1991. Abrupt deep-sea warming, palaeoceanographic changes and benthic extinctions at the end of the Paleocene. Nature 353: 225-229.

Krishnan S, Pagani M, Huber M, Sluijs A. 2014. High latitude hydrological changes during the Eocene Thermal Maximum 2. Earth Planet. Sc. Lett. 404: 167-177.

Ladd SN, Sachs JP. 2013. Positive correlation between salinity and $n$ alkane $\delta 13 \mathrm{C}$ values in the mangrove Avicennia marina. Org. Geoch. 64: 1-8.

Lauretano V, Littler K, Polling M, Zachos JC, Lourens LJ. 2015. Frequency, magnitude and character of hyperthermal events at the onset of the Early Eocene Climatic Optimum. Clim. Past. 11: 1313-1324.

Littler K, Röhl U, Westerhold T, Zachos JC. 2014. A high-resolution benthic stable-isotope record for the South Atlantic: Implications for orbital-scale changes in Late Paleocene-Early Eocene climate and carbon cycling. Earth Planet. Sc. Lett. 401: 18-30.

Lourens LJ, Sluijs A, Kroon D, et al. 2005. Astronomical pacing of late Palaeocene to early Eocene global warming events. Nature 435: 1083-1087.

Magioncalda R. 2004. Chémostratigraphie de la limite Paléocène/ Eocène (CIE) fondée sur l'étude de la composition isotopique du carbone organique $\left(\delta^{13} \mathrm{C}_{\text {org }} \% \mathrm{PDB}\right)$. Application pour la mise en corrélation de successions continentales, lagunaires et marines. $\mathrm{PhD}$ thesis, Faculté Polytechnique de Mons, Mons, 220 p.

Magioncalda R, Dupuis C, Blamart D, et al. 2001. L'excursion isotopique $\mathrm{du}$ carbone organique (delta 13C org) dans les paleoenvironnements continentaux de l'intervalle Paleocene/ Eocene de Varangeville (Haute-Normandie). B. Soc. Géol. Fr. 172: 349-358.

Magioncalda R, Dupuis C, Smith T, Steurbaut E, Gingerich, PD. 2004. Paleocene-Eocene carbon isotope excursion in organic carbon and pedogenic carbonate: Direct comparison in a continental stratigraphic section. Geology 32: 553-556.

McInerney FA, Wing SL. 2011. The Paleocene-Eocene Thermal Maximum: A Perturbation of Carbon Cycle, Climate, and Biosphere with Implications for the Future. Annu. Rev. Earth Pl. Sc. 39: 489-516.

Methner K, Lenz O, Riegel W, Wilde V, Mulch A. 2019. Paleoenvironmental response of midlatitudinal wetlands to Paleocene-early Eocene climate change (Schöningen lignite deposits, Germany). Clim. Past. 15: 1741-1755.

Meyers PA. 1997. Organic geochemical proxies of paleoceanographic, paleolimnologic, and paleoclimatic processes. Org. Geoch. 27: 213-250.

Murphy BH, Farley KA, Zachos JC. 2010. An extraterrestrial 3Hebased timescale for the Paleocene-Eocene thermal maximum (PETM) from Walvis Ridge, IODP Site 1266. Geochim. Cosmochim. Ac. 74: 5098-5108. 
Noiret C, Steurbaut E, Tabuce R, et al. 2016. New bio-chemostratigraphic dating of a unique early Eocene sequence from southern Europe results in precise mammalian biochronological tie-points. Newsl. Stratigr. 49: 469-480.

Odin GS. 1982. Interlaboratory standards for dating purposes. In: Odin GS, ed. Numerical Dating in Stratigraphy. New York, pp. 123-158.

Odin GS, Matter A. 1981. De glauconiarum origine. Sedimentology 28: 611-641.

Pujalte V, Robador A, Payros A, Samsó JM. 2016. A siliciclastic braid delta within a lower Paleogene carbonate platform (Ordesa-Monte Perdido National Park, southern Pyrenees, Spain): Record of the Paleocene-Eocene Thermal Maximum perturbation. Palaeogeogr. Palaeoclimatol. Palaeoecol. 459: 453-470.

Renne PR, Swisher CC, Deino AL, Karner DB, Owens TL, DePaolo DJ. 1998. Intercalibration of standards, absolute ages and uncertainties in 40Ar/39Ar dating. Chem. Geol. 145: 117-152.

Rommerskirchen F, Eglinton G, Dupont L, et al. 2003. A north to south transect of Holocene southeast Atlantic continental margin sediments: Relationship between aerosol transport and compoundspecific $\delta^{13} \mathrm{C}$ land plant biomarker and pollen records. Geoch. Geoph. Geos. 4(12): 1101.

Sachse D, Billault I, Bowen GJ, et al. 2012. Molecular Paleohydrology: Interpreting the Hydrogen-Isotopic Composition of Lipid Biomarkers from Photosynthesizing Organisms. Annu. Rev. Earth Pl. Sc. 40: 221-249.

Schwark L, Zink K, Lechterbeck J, 2002. Reconstruction of postglacial to early Holocene vegetation history in terrestrial Central Europe via cuticular lipid biomarkers and pollen records from lake sediments. Geology 30(5): 463-466.

Sluijs A, Pross J, Brinkhuis H, 2005. From greenhouse to icehouse; organic-walled dinoflagellate cysts as paleoenvironmental indicators in the Paleogene. Earth-Sci. Rev. 68: 281-315.

Sluijs A, Schouten S, Pagani M, et al. 2006. Subtropical Arctic Ocean temperatures during the Palaeocene/Eocene thermal maximum. Nature 441: 610-613.

Sluijs A, Bijl PK, Schouten S, Röhl U, Reichart G-J, Brinkhuis H, 2011. Southern Ocean warming, sea level and hydrological change during the Paleocene-Eocene thermal maximum. Clim. Past. 7: 47-61.

Sluijs A, van Roij L, Frieling J, Laks J, Reichart G-J, 2018. Singlespecies dinoflagellate cyst carbon isotope ecology across the Paleocene-Eocene Thermal Maximum. Geology 46(1): 79-82.

Smith FA, Freeman KH. 2006. Influence of physiology and climate on $\delta \mathrm{D}$ of leaf wax n-alkanes from $\mathrm{C}_{3}$ and $\mathrm{C}_{4}$ grasses. Geochim. Cosmochim. Ac. 70: 1172-1187.

Smith T, Rose KD, Gingerich PD. 2006. Rapid Asia-Europe-North America geographic dispersal of earliest Eocene primate Teilhardina during the Paleocene-Eocene thermal maximum. P. Natl. Acad. Sci. USA 103: 11223.

Speelman EN, Sewall JO, Noone D, et al. 2010. Modeling the influence of a reduced equator-to-pole sea surface temperature gradient on the distribution of water isotopes in the Early/Middle Eocene. Earth Planet. Sc. Lett. 298: 57-65.

Spell TL, McDougall I. 2003. Characterization and calibration of 40Ar/39Ar dating standards. Chem. Geol. 198: 189-211.

Steiger RH, Jäger E. 1977. Subcommission on geochronology: Convention on the use of decay constants in geo- and cosmochronology. Earth Planet. Sc. Lett. 36: 359-362.

Steurbaut E, Magioncalda R, Dupuis C, van Simaeys S, Roche E, Roche M. 2003. Palynology, paleoenvironments, and organic carbon isotope evolution in lagoonal Paleocene-Eocene boundary settings in North Belgium. Geol. S. Am. S. Pap. 369: 291-317.

Storme J-Y, Dupuis C, Schnyder J, et al. 2012. Cycles of humid-dry climate conditions around the P/E boundary: new stable isotope data from terrestrial organic matter in Vasterival section (NW France). Terra Nova 24: 114-122.

Tappert R, McKellar RC, Wolfe AP, Tappert MC, Ortega-Blanco J, Muehlenbachs K. 2013. Stable carbon isotopes of C3 plant resins and ambers record changes in atmospheric oxygen since the Triassic. Geochim. Cosmochim. Ac. 121: 240-262.

Tyson RV. 1995. Sedimentary organic matter. Organic facies and palynofacies. London: Chapman and Hall, $650 \mathrm{p}$.

Vandenberghe N, Hilgen FJ, Speijer RP. 2012. The Paleogene period. In: Gradstein, et al., eds. The Geological Time Scale 2012. Amsterdam: Elsevier Science Ltd, pp. 855-921.

Westerhold T, Röhl U, Frederichs T, et al. 2017. Astronomical calibration of the Ypresian timescale: implications for seafloor spreading rates and the chaotic behavior of the solar system? Clim. Past. 13: 1129-1152.

Westerhold T, Röhl U, Wilkens RH, et al. 2018. Synchronizing early Eocene deep-sea and continental records-cyclostratigraphic age models for the Bighorn Basin Coring Project drill cores. Clim. Past. 14: 303-319.

Yans J, Gerards T, Gerrienne P, et al. 2010. Carbon-isotope analysis of fossil wood and dispersed organic matter from the terrestrial Wealden facies of Hautrage (Mons Basin, Belgium). Palaeogeogr. Palaeoclimatol. Palaeoecol. 291: 85-105.

Yans J, Marandat B, Masure E, et al. 2014. Refined bio- (benthic foraminifera, dinoflagellate cysts) and chemostratigraphy $\left(\delta^{13} \mathrm{C}_{\mathrm{org}}\right)$ of the earliest Eocene at Albas-Le Clot (Corbières, France): implications for mammalian biochronology in Western Europe. Newsletters on Stratigraphy 47/3: 331-353.

Zachos JC, Röhl U, Schellenberg SA, et al. 2005. Rapid Acidification of the Ocean during the Paleocene-Eocene Thermal Maximum. Science, New Series 308: 1611-1615.

Cite this article as: Garel S, Dupuis C, Quesnel F, Jacob J, Yans J, Magioncalda R, Fléhoc C, Schnyder J. 2020. Multiple early Eocene carbon isotope excursions associated with environmental changes in the Dieppe-Hampshire Basin (NW Europe), BSGF - Earth Sciences Bulletin 191: 33 . 